\title{
Memorial do convento: $o$ romance histórico encontra a tragédia grega
}

\author{
Filipe Nassar Larêdo ${ }^{1}$
}

\begin{abstract}
RESUMO: O presente artigo nasce da hipótese de que o romance histórico Memorial do convento, de José Saramago, publicado em 1982, traz, em sua composição, traços característicos da tragédia grega que contribuem para a formação de caminhos para uma nova leitura do romance histórico, de modo que possam expandir a percepção do leitor sobre o gênero, por meio de reflexões despertadas pelos referenciais literários que a obra nos sugere. Sob tal perspectiva, e com o objetivo de aproximar os conceitos de tragédia grega ao romance histórico construído por Saramago, traremos os conceitos do historiador austríaco Albin Lesky (2003) que, em sua obra A tragédia grega, enxerga o trágico como um princípio filosófico revelador de uma visão específica do mundo. Como suporte para a reflexão aqui proposta, utilizaremos também os argumentos do historiador francês Jean-Pierre Vernant (2006), os quais, cruzados com a perspectiva de Alcmeno Bastos (2007) sobre o romance histórico e com a de Benedito Nunes (2013) sobre o romantismo, encontrar-se-ão com os do inglês Terry Eagleton (2013). Teresa Cristina Cerdeira da Silva (2018), por sua vez, uma das maiores pesquisadoras da obra de Saramago, no Brasil, é outra referência em nossas reflexões, visto que, em alguns de seus estudos, ocorrem sugestões instigantes para uma aproximação entre o romance em questão e certos aspectos da tragédia.
\end{abstract}

PALAVRAS-CHAVE: José Saramago; Memorial do convento; Gênero trágico.

\section{Memorial do convento: the historical novel meets the greek tragedy}

\begin{abstract}
This article is based on the hypothesis that José Saramago's historical novel, Memorial do convento, published in 1982, displays some traits of the Greek tragedy that contribute to the development of paths to a new comprehension of historical novel, expanding the reader's perception of the genre, through reflections elicited by the literary references implied in the novel. From this perspective, and with the aim of bringing the concepts of Greek tragedy closer to the historical novel composed by Saramago, we are going to look into the concepts developed by the Austrian historian Albin Lesky (2003), who in his work The Greek tragedy perceives the tragic as a philosophical principle that reveals a specific outlook on the world. Supporting the reflections proposed here, we also mention some arguments of the French historian Jean-Pierre Vernant (2006), those which, intertwined with Alcmeno Bastos's (2007) perception of historical novel and Benedito Nunes's (2003) perception of romanticism, concur with the arguments of Terry Eagleton (2013). In Brazil, Teresa Cristina Cerdeira da Silva (2018), one of the greatest researchers of Saramago's work, is another reference to our analysis, since some of her studies suggest a thought-provoking approximation between Memorial do convento and certain aspects of tragedy.
\end{abstract}

KEYWORDS: José Saramago. Memorial do convento. Tragedy.

\section{O romance Memorial do convento}

Em Memorial do convento, o autor português José Saramago, ganhador do Prêmio Nobel

\footnotetext{
${ }^{1}$ Mestre em Literatura e Crítica Literária pela Pontifícia Universidade Católica de São Paulo.
} 
de Literatura em 1998, propõe um novo enfoque sobre os fatos históricos que envolveram a construção do Palácio Nacional de Mafra, no início do século XVIII, pelo então monarca absolutista de Portugal, D. João V. Esse evento, cujo palco foi o início da Guerra de Sucessão da Espanha, em 1704, teve como motivação um contexto fundamentalmente mercantilista, em que as potências econômicas lutavam pela primazia comercial nas colônias ultramarinas.

Assim, em perspectiva ficcional, Memorial do convento reescreve a Guerra de Sucessão, que se iniciou em decorrência da morte do rei Carlos II, em 1699. A vacância do trono fez com que poderosas nações o disputassem: França, Holanda, Alemanha, o bloco austríaco, Inglaterra (que se tornou a grande vitoriosa) e, finalmente, Portugal - que representava os pequenos países e não viu o cumprimento das promessas feitas, embora estivesse alinhado com os vencedores.

Por reconstruir parte do século XVIII, período em que João V era rei de Portugal e levou a cabo uma construção de proporções magníficas, o romance oferece, dentre outras possibilidades, uma leitura diferente dos acontecimentos registrados nos manuais de História sobre essa época. Assim, Saramago constrói pistas acerca de aparentes heróis, quando elege o rei e a rainha para iniciarem a narrativa, utilizando tons jocosos e satíricos, incompatíveis com a magnificência real, o que os deslocará do protagonismo - eixo tradicional de leitura do passado, comprometido com a nobreza e o clero - para um segundo plano, de forma a fazer emergir o povo e seus personagens marginais, agora transformados em heróis da trama, nessa nova versão.

Em Memorial do convento, Saramago avança em derivações de um gênero que, no contexto da literatura portuguesa, apresenta inúmeras realizações desde tempos mais remotos: o romance histórico. As novelas de cavalaria e mesmo as cantigas medievais já articulavam acontecimentos históricos com dados e personagens constituídos por manifestações do imaginário.

No romance em questão, gênero representante dos tempos modernos, o leitor se surpreende contextualizado com a monarquia absolutista portuguesa, interagindo com personagens religiosas extremamente poderosas, em situações que se movimentam entre as expectativas de um rei que clama por um herdeiro e os anseios da Igreja por ampliar espaços, projetando, para isso, a construção do Palácio Nacional de Mafra, em Lisboa. A realidade textual toma corpo assim, mesclando aos registros oficiais uma história traçada em tons poéticos que fazem perder de vista onde se inscreve o que um dia foi realidade e o que hoje é ficção.

É nesse espaço histórico que somos apresentados a protagonistas como Baltasar Mateus (ex-soldado e maneta), sua amada Blimunda (detentora do poder de ver por dentro as pessoas, 
desde que esteja em jejum), e o padre Bartolomeu de Gusmão (brasileiro e projetista da passarola, um protótipo de avião que demanda energia etérea para voar).

A trama narrativa, conforme já colocado, inicia-se com D. João $\mathrm{V}, 24^{\circ}$ monarca de Portugal. Vaidoso, esse rei viu-se obrigado a iniciar a construção do Convento de Mafra como ficou conhecido o palácio - para cumprir uma promessa que fizera ao Frei Antônio de São José, a fim de garantir as bênçãos para a fecundação da rainha, D. Maria Ana Josefa, e o consequente nascimento de seu sucessor. Nesse episódio, D. João V verá consumirem-se inúmeras riquezas vindas da Índia e da colônia brasileira, assim como a vida de muitos operários.

É verdade o que acaba de dizer-me sua eminência, que se eu prometer levantar um convento em Mafra terei filhos, e o frade respondeu, Verdade é, senhor, porém só se o convento for franciscano, e tornou el-rei, Como sabeis, e frei António disse, Sei, não sei como vim a saber, eu sou apenas a boca de que a verdade se serve para falar, a fé não tem mais que responder, construa vossa majestade o convento e terá brevemente sucessão, não o construa e Deus decidirá. (SARAMAGO, 2017, p. 12-13).

A construção é iniciada, oficialmente, com uma imensa quantidade de trabalhadores envolvidos, o que marca a história de Portugal, seja pela grandiosidade do palácio, seja pelas inúmeras formas de sofrimento oriundas desse evento. Importante salientar o sofrimento, em especial, do povo marginalizado, que se viu envolvido em uma espécie de delírio de luxo às custas das minas brasileiras, por ocasião da chegada a Lisboa do primeiro carregamento do recém-descoberto ouro em 1699, riqueza em abundância que sustentaria Portugal por aproximadamente cinquenta anos.

O sofrimento do povo português — forçado a lutar por motivos meramente econômicos, dos quais dificilmente se beneficiaria - fica bastante claro quando verificamos que:

A tropa andava descalça e rota, roubava os lavradores, recusava-se a ir à batalha, e tanto desertava para o inimigo como debandava para as suas terras, metendo-se fora dos caminhos, assaltando para comer, violando mulheres desgarradas, cobrando, enfim, a dívida de quem nada lhes devia e sofria desespero igual. Sete-sóis, mutilado, caminhava para Lisboa pela estrada real, credor de uma mão esquerda que ficara parte em Espanha e parte em Portugal, por artes de uma guerra em que se haveria de decidir quem viria a sentar-se no trono da Espanha, se um Carlos austríaco ou um Filipe francês, português nenhum [...] (SARAMAGO, 2017, p. 36). 
Concomitante ao sofrimento do povo, outro cenário se colocava como aberrante naquele contexto: a abundância de riquezas trazidas das colônias, em especial do Brasil, base da economia portuguesa em meados do século XVI. Apesar de já trazerem das terras brasileiras a madeira, o açúcar, o tabaco, a mandioca e o algodão, foi com a descoberta do ouro que se inaugurou uma febre de riqueza sem precedentes na história portuguesa. Todavia, não foi assumida pela nação a prerrogativa de fixar as riquezas recém-chegadas em seu território, deixando-as esvaírem-se em toda a espécie de supérfluos, usufruídos pelos detentores do poder político e econômico.

Como uma figura alegórica que tensiona o elo entre os sofrimentos do povo português e o ouro brasileiro, surge a construção do que seria um meio convento, meio palácio, na vila de Mafra. A gigantesca obra é iniciada configurando o cumprimento da promessa de D. João V, que passa a adquirir todos os terrenos necessários para a construção, até que, em 1711, lança oficialmente a primeira pedra, cuja cerimônia "teria custado em torno de 200000 cruzados (80 contos de ouro)" (CERDEIRA, 2018, p. 46).

A construção cresce em conformidade com as indecisões do rei quanto às dimensões que o convento deveria ter. Assim, o projeto inicial — nitidamente marcado por influências arquitetônicas estrangeiras, bem ao costume de Portugal daquele século — destinado a abrigar 13 frades, torna-se um magnânimo convento-palácio para comportar 300 religiosos, além de receber a família real e toda a sua corte.

Os motivos pelos quais o rei D. João V se vê compromissado a construir o convento, e depois o palácio nacional, dão ao leitor indicativos do poder que a Igreja Católica tinha naquele período, incluindo a prerrogativa de fazer julgamentos, decretar e executar sentenças de desterro e de morte, por meio dos tribunais da fé da Santa Inquisição.

\subsection{A ambiência religiosa em Portugal do século XVIII e seu impacto na trama da personagem Blimunda}

Importante para a caracterização da ambiência religiosa em Portugal do século XVIII, a Inquisição foi instalada como fruto da bula papal concedida em 1536, após três anos da requisição por parte de D. João III, e possuía, segundo Bethencourt (2000, p. 10), "um estatuto particular que se traduz por uma quase completa independência de ação em relação à cúria romana”, o que revela a especial influência que ela possuía para modificar e estimular as decisões do rei de Portugal. Segundo Cerdeira (2018), não restam dúvidas quanto aos motivos que teriam justificado tal procedimento em terras portuguesas, em nome da ameaça judaica e 
como possibilidade de enriquecimento da Coroa por meio dos bens confiscados aos judeus condenados.

Além dos judeus, a Inquisição "perseguia ainda outros crimes, inimigos da fé: a bigamia, a homossexualidade e a magia" (CERDEIRA, 2018, p. 49). Seus julgamentos conduziam a penas variadas - desde o açoite e a prisão perpétua até o degredo, o garrote e a fogueira —, as quais caracterizavam a função do sofrimento nos supliciados que, por sua vez, transmitiam as infâmias de que eram alvos àqueles ligados aos seus nomes por laços de família, e até às gerações futuras.

Esses laços de família nos aproximam novamente da protagonista, Blimunda, e fazemnos destacar alguns aspectos peculiares do romance.

Sobre a mãe de Blimunda, temos:

[...] um quarto de cristã-nova, que tenho visões e revelações, mas disseramme no tribunal que era fingimento, que ouço vozes do céu, mas explicaramme que era efeito demoníaco, que sei que posso ser santa como os santos o são, ou ainda melhor, pois não alcanço a diferença entre mim e eles, mas repreenderam-me de que isso é presunção insuportável e orgulho monstruoso [...]" (SARAMAGO, 2017, p. 54).

$\mathrm{Na}$ narrativa saramaguiana, Blimunda, de certa forma, herda da mãe certos atributos mágicos, dentre os quais o que mais se destaca na trama é o dom de "olhar por dentro das pessoas" (SARAMAGO, 2017, p. 80). Entretanto, seu dom é diferente das práticas da mãe: “[...] não é heresia, nem é feitiçaria, os meus olhos são naturais [...] Vejo o que está dentro dos corpos, e às vezes o que está no interior da terra, das roupas, mas só vejo quando estou em jejum.” (SARAMAGO, 2017, p. 81).

Blimunda assiste ao suplício de sua mãe, escondendo seus suspiros e lágrimas, sem poder proferir palavra alguma, além de ser forçada a fingir que não a conhece, e mesmo que a despreza. Sebastiana de Jesus, em seu percurso, é atingida por imundícies vindas das pessoas que acompanham o evento. O soldado Baltasar Sete-Sóis acompanha a dor de Blimunda Sebastiana de Jesus.

A cena que se apresenta no início do romance é relevante para o presente estudo por tratar-se de um momento de grande perda para a protagonista que, ao final, viverá novamente a situação de dor extrema, quando testemunhar o homem amado morrendo como condenado, nas chamas da fogueira inquisitorial.

Nos dizeres de Cerdeira (2018, p. 54), "trata-se do momento crucial da tragédia que separa Blimunda e Baltasar, depois que este desaparecera no céu, levado pela passarola.” 


\section{Memorial do convento como tragédia grega}

Neste tópico, trazemos aspectos que apontam para o entendimento de como a tragédia grega, em seu contexto histórico, pode aproximar-se de Memorial do convento, contribuindo para a formação de caminhos para uma nova leitura do romance histórico, de modo que possa expandir a percepção do leitor sobre o gênero, por meio de reflexões despertadas pelos referenciais literários que a obra nos sugere.

Faremos a pavimentação do caminho proposto por Memorial do convento, utilizando principalmente o posicionamento de Lesky (2015), que se encontrará com o de Vernant (2011), ambos historiadores que analisaram mais detalhadamente os fundamentos das tragédias gregas, além do filósofo Eagleton (2013), que abordou aspectos democráticos em literatura, os quais se mostram fundamentais para entendermos a articulação das camadas populares como protagonistas na narrativa.

Antes de avançarmos nas possíveis relações entre o romance e a tragédia grega, faz-se mister estabelecermos conexões, quiçá seminais, entre determinados aspectos trágicos e algumas características formadoras do romance histórico presentes na obra em questão. Para isso, utilizamos os contornos definidos sobre a vontade na tragédia grega, desenvolvidos por Jean-Pierre Vernant (2006), e cruzamos com os estudos do pesquisador brasileiro Alcmeno Bastos (2007), em Introdução ao romance histórico.

Para Vernant (2006, p. 25), a vontade é tida como "umas das dimensões essenciais da pessoa", vista em seu aspecto de agente. A vontade seria o eu como fonte de atos "pelos quais ele não somente é responsável diante de outrem, mas também aos quais se sente preso interiormente" (VERNANT, 2006, p. 25). Além disso, constitui a semente que marca a diferenciação entre a epopeia, a poesia lírica e a tragédia. Isso ocorre devido ao processo de continuidade do sujeito, que traz do passado suas memórias e torna-se internamente responsável, no presente, por aquilo que fez ontem.

Essa continuidade leva o sujeito para um outro processo, dessa vez o da individuação da vontade. Embora Lesky (2015) recorra à inevitabilidade da queda do sujeito trágico, Vernant (2011, p. 28) nota que existe uma dupla motivação do herói, quando esse "confronta-se com uma necessidade superior que se impõe a ele, que o dirige", mas que deixa espaço para a intervenção do caráter do herói na efetivação dos acontecimentos.

A intervenção do caráter do herói é o que proporciona o advento do indivíduo, em especial quando este é apreendido em sua função de agente, fazendo surgir uma 
responsabilidade subjetiva em substituição ao delito objetivo.

Vernant (2011) utiliza o herói esquiliano como reflexo dessa intervenção, como é possível ver em Prometen acorrentado que, mesmo privado de escolha por estar preso e submetido a sofrimentos eternos, não é nem um pouco passivo. A dependência do divino não submete o homem — ou o protagonista da tragédia esquiliana — de maneira mecânica, inibindo sua vontade.

Quando o herói é questionado no palco, diante do público, é o próprio homem grego que se descobre trágico. Enquanto a epopeia "apresentava as grandes figuras dos heróis de outrora como modelos", os espetáculos trágicos trouxeram o herói lendário, cujos valores, glórias, virtudes e grandes feitos eram cantados pela epopeia, para o debate "através do jogo dos diálogos, do confronto dos protagonistas com o coro, das intervenções da situação durante o drama” (VERNANT, 2011, p. 161).

O indivíduo, então, é apreendido na sua função de agente, tornando-se elemento constitutivo da antropologia trágica — no plano da experiência humana, uma vez que o homem e sua ação aparecem, na perspectiva própria da tragédia, como um problema, e não como realidade estável —, e gera, por meio de diversos níveis intencionais, a aparição de uma responsabilidade subjetiva que substitui o delito objetivo, a realidade definida e julgada.

Dessa forma, é possível aproximar o romance em questão da tragédia grega, no que se refere aos questionamentos que o escritor português manifesta ao construir uma narrativa diferente do tradicional romance histórico.

Embora reconheça o hibridismo incontornável do romance histórico, Alcmeno Bastos (2007) faz sua reflexão sobre o gênero e tenta montar uma conceituação da modalidade. Em torno das relações entre o romance e a epopeia, Bastos (2007) ressalta a natureza aberta da poética do romance, o que permite a recepção de outras formas literárias, alinhando-se, dessa forma, ao pensamento de Linda Hutcheon (HUTCHEON, 1991, p. 127 apud BASTOS, 2007, p. 80), quando esta afirma que não "apenas a história tem uma pretensão à verdade", mas também a ficção pode pretendê-la.

Dentre os traços propostos por Alcmeno Bastos (2007, p. 78) para caracterizar o romance histórico tradicional, destacamos: "representação de um passado remoto, dicção triunfalista, heroicização idealizada do protagonista, nacionalismo exaltatório". O próprio Bastos (2007, p. 76) indica os aspectos de um novo romance histórico, dentre os quais destacamos "a ausência de triunfalismo, a diversificada perspectiva temporal do narrador, a explicitação de sua natureza ficcional e consequente caráter autorreflexivo, intertextual, além da frequente recorrência à paródia". 


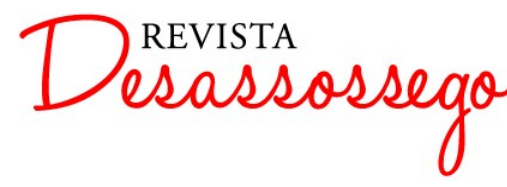

DESASSOSSEGO 20 - parte 2 |JUN/2019 | ISSN 2175-3180

DOI: http://dx.doi.org/10.11606/issn.2175-3180.v11i20p251-268

A conexão entre a subjetivação do herói lendário na tragédia e o rompimento dos traços caracterizadores do romance histórico tradicional entrelaçam-se. O protagonista no romance histórico tradicional é marcado por representações virtuosas, códigos de conduta moralistas e modelos a serem reproduzidos, o que, de certa forma, ocorria nas epopeias, com seus heróis lendários. "O herói deixa de se apresentar como modelo, como era na epopeia e na poesia lírica: ele se tornou um problema.” (VERNANT, 2011, p. 215). Sendo assim, é possível verificar uma aproximação conceitual entre as tragédias gregas e os novos romances históricos, tratados respectivamente por Vernant (2011) e Bastos (2007).

Por fim, é importante destacar dois fatores relacionados ao alcance que as referidas conexões podem ter, no que diz respeito à explicitação da natureza ficcional presente em ambos os gêneros. O primeiro deles se constata quando Vernant (2011, p. 162) deixa clara sua posição, ao afirmar que "na cultura grega, a tragédia abre [assim] um novo espaço, o do imaginário, sentido e compreendido como tal, isto é: como uma obra humana decorrente do puro artifício". Cria-se, portanto, uma consciência da ficção, que é "constitutiva do espetáculo dramático: ela aparece ao mesmo tempo como sua condição e como seu produto" (VERNANT, 2011, p. 216).

O segundo fator nos leva novamente ao momento em que falamos sobre a apreensão do indivíduo em sua função de agente, o que nos indica a necessidade de fazermos uma breve digressão acerca das bases filosóficas que proporcionaram a ascensão do Romantismo, uma vez que Alcmeno Bastos (2007, p. 11) vê o romance histórico como legítimo fruto do Romantismo, que "de tal modo identificou-se com o modelo romântico [...] que esse modelo foi tomado não como uma de suas figurações possíveis [...] mas como sua forma inevitável”".

Para falarmos sobre a apreensão do indivíduo em sua função de agente, utilizamos o texto “A visão romântica”, de Benedito Nunes (2013), no qual o filósofo afirma ter sido apenas na época do Romantismo que o caráter conflituoso interiorizado adquiriu status de categoria universal, concretizando-se no plano literário e artístico. Dos diversos caracteres sintomáticos para a constituição da visão romântica, Nunes destaca alguns que se tornaram pertinentes para justificar os presentes argumentos. Dentre eles, constam, além da mecanização e da racionalização da vida, pontos abordados anteriormente: "a justificativa ideológica da religião como instrumento legitimador do poder e da ordem" (NUNES, 2013, p. 55).

O indivíduo passa a ser elemento preponderante na construção da realidade, transferindo o protagonismo do sagrado para o terreno, uma vez que o "circuito entre o interior e o exterior depende agora do sujeito, que transcende" (NUNES, 2013, p. 57), assim avultando em toda parte relações de si para si mesmo. 
Para nos assegurarmos de que os argumentos trazidos por Nunes (2013) sobre o indivíduo como sujeito de sentimentos encontrem proximidade com os efeitos dos fenômenos trágicos, retomamos Jaeger (1989, p. 205-206):

Assim, o coro, de narrador lírico, converteu-se em ator e, portanto, um sujeito de sentimentos que até então apenas havia partilhado e acompanhado com as suas emoções. Era, pois, estranha à essência desta forma mais antiga da tragédia qualquer representação pormenorizada e mínima das ações comuns da vida.

O coro converte-se em ator quando a fecundidade artística e entusiasmo ditirâmbico se encontram. Dessa forma o coro é capaz de traduzir, em uma representação cênica, os próprios sentimentos do ator.

\subsection{Um novo contorno para o herói}

Na mesma esteira de Nunes (2013), porém direcionando seus argumentos para os aspectos trágicos na literatura, Terry Eagleton, em Doce violência, não vê diferenciação entre tragédia e vida rotineira, encontrando igualdade universal e valor singular em cada indivíduo e considerando que qualquer um pode ser uma figura trágica, em especial a partir das mudanças trazidas pelo Iluminismo - período histórico cuja força motriz foi a mesma que moveu o surgimento do Romantismo.

Heróis e heroínas podem agora ser encontrados flanando em qualquer esquina, pois o destino de cada indivíduo torna-se, em princípio, tão precioso quanto o de todos os outros, e a sua crise histórico-global ameaça abalar a minha também. (EAGLETON, 2013, p. 142).

Para Eagleton (2013), as possibilidades de inclusão do indivíduo comum no extremo limite de sua capacidade de resistência, como sujeito trágico, fazem com que a tragédia deixe de ser um território privilegiado de deuses e gigantes espirituais e passe a ser território democratizado.

Com a democracia, entretanto, as coisas são diferentes, pois agora se tem por certo que homens e mulheres são singularmente valiosos [...] Para ganhar nossa simpatia, eles não precisam ser duquesas, guerrilheiros, combatentes destemidos na batalha da vida, vítimas desafortunadas de um destino hostil, inocentes morais ou profundamente conscientes de seus apuros [...] É por isso que, sob a democracia, os protagonistas trágicos não precisam ser heróis para serem trágicos. (EAGLETON, 2013, p. 142). 
Sobre esse ponto, Eagleton (2013) considera o debate acerca de protagonistas superiores e inferiores irrelevante, incluindo o povo, a classe social, a gente operária como protagonistas de tragédias. Eagleton (2013, p. 146) mostra o exemplo de Germinal, de Zola, como "uma das melhores tragédias sobre a vida da classe operária". Seguindo essa linha, é possível transportar os mesmos argumentos para Memorial do convento. Vejamos:

Talvez Deus seja um, talvez seja três, pode bem ser que seja quatro, a diferença não se nota, se calhar Deus é o único soldado vivo de um exército de cem mil, por isso é ao mesmo tempo soldado, capitão e general, e também maneta. (SARAMAGO, 2017, p. 191).

Segundo Eagleton (2013), nessa realidade há uma mudança do herói para a vítima, verificável com profusão na tragédia grega em Eurípedes, que traz para o terreno trágico o indivíduo comum, sem grandes traços mítico-lendários. Vejamos o caso de Medeia, peça na qual a heroína - que, assim como Blimunda, é descendente de uma linhagem de feiticeiras é construída para denunciar a condição da mulher na sociedade patriarcal grega. Preterida por Jasão, a protagonista vê seus direitos conjugais lesados ao ser substituída por outra mulher. Duplamente sem pátria, já que traíra seu pai e matara seu irmão, decide punir Jasão, ao que é apoiada pelo coro de mulheres coríntias que a cerca.

O meu marido, que era tudo para mim — isso eu sei bem demais —, tornouse um homem péssimo. Das criaturas todas que têm vida e pensam, somos nós, as mulheres, as mais sofredoras. (EURÍPEDES et al., 2013, p. 212).

Para Werner Jaeger, em Paidéia (1989), a representação do mito na tragédia não se limita à dramatização exterior, mas penetra no que o indivíduo tem de mais profundo, tornando-o agente na narrativa. Assim, os "sucessores de Ésquilo, Eurípedes principalmente, foram mais além, a ponto de converterem a tragédia mítica numa representação da vida quotidiana" (JAEGER, 1989, p. 206), o que favorece a hipótese de aproximação entre a tragédia grega e o romance histórico de José Saramago.

Para os gregos antigos, segundo Jaeger (1989), é possível encontrar a questão do trágico como uma expressão de cultura indivisível que abrangia religião, filosofia, direito, política, arte, e não apenas uma pura dimensão artística. É com a tragédia que o ser humano pode atingir a capacidade de unidade, é com ela que nasce um novo espírito de heroísmo mais interior e mais profundo, pois ela parte de um conhecimento reflexivo para as emoções mais sensíveis.

Além de Jaeger (1989), também vemos em Nietzsche (2017, p. 71) essa mudança radical no papel do herói nas tragédias, que se abrem para atributos de pessoas comuns: 
Por seu intermédio, o homem da vida cotidiana deixou o âmbito dos espectadores e abriu caminho até o palco [...] Odisseu, o heleno típico da arte antiga, vai agora baixando sob as mãos dos novos poetas, até a figura do graeculus, que doravante, como escravo doméstico, bonachão e espertalhão, está no centro do interesse dramático.

Para validar nossa proposta - aproximar os conceitos de tragédia grega ao romance histórico construído por Saramago —, somos impulsionados a realizar a conexão entre Prometeu e o padre Bartolomeu de Gusmão.

Embora possamos encontrar outras aproximações possíveis, elegemos especificamente os dois em virtude de Ésquilo, o autor de Prometeu acorrentado, ser considerado por Mário da Gama Kury — na introdução que este faz à peça em $O$ melhor do teatro grego — o "primeiro poeta trágico" (EURÍPEDES et al., 2013, p. 21).

Para iniciarmos essa aproximação, é importante destacar que, convergindo com uma das características apontadas por Alcmeno Bastos (2007), na Grécia antiga:

O mito era tido como o registro de um passado remoto e o presente era muitas vezes interpretado com base em categorias do mito, em que o tempo cíclico e manifestações do fantástico são admissíveis. (KURY, in EURÍPEDES et al., 2013, p. 22).

Prometeu acorrentado é uma tragédia cujo herói é o protetor da humanidade, à qual, com o dom do fogo, apresenta as artes e as ciências, rivalizando com Zeus, tirano que proibira previamente o acesso dos homens a esses conhecimentos. Por sua desobediência, Prometeu é condenado pelo soberano Zeus a passar a eternidade aprisionado, e seu sofrimento é exibido como forma de modelo a todos os que se atrevam a cometer o mesmo erro. Por diversas vezes, Prometeu é aconselhado por outros deuses a rever seus atos, em troca da clemência de Zeus, mas ele se mostra inflexível a qualquer tentativa conciliatória, numa arrogância e obstinação que beiram a loucura.

Verificamos aqui um traço bastante marcante do herói esquiliano que, "mesmo privado de escolha em sua decisão, não é nem um pouco passivo" (VERNANT, 2011, p. 29). Prometeu tem a oportunidade de desfazer sua punição, mas não o faz. Assim, retomamos à questão da dupla motivação do herói, que se confronta com uma força maior, a qual o dirige, mas que toma para si essa necessidade — no caso o amor que sente pela humanidade — e decide aceitar a punição final da tragédia.

A recusa incondicional a qualquer proposta conciliatória fica bem visível na tragédia esquiliana, quando se verifica a forma como Prometeu se refere a Zeus e como responde às 
Desassossego

tratativas de Oceano e Hermes:
DESASSOSSEGO 20 - parte 2 |JUN/2019 | ISSN 2175-3180

DOI: http://dx.doi.org/10.11606/issn.2175-3180.v11i20p251-268

\section{HERMES}

Tuas maneiras imutáveis e inflexíveis trouxeram-te a este ancoradouro de dores.

\section{PROMETEU}

Fica sabendo ainda: nunca eu trocaria minha desdita pela tua submissão. Acho melhor ficar preso a este rochedo que me ver transformado em fiel mensageiro de Zeus, senhor dos deuses! Assim mostrarei aos orgulhosos quão vazio é seu orgulho. (EURÍPEDES et al., 2013, p. 79).

A decisão de Prometeu no espetáculo trágico promove o processo de individuação da vontade, cujo protagonista elabora e apreende sua função de agente, tendo consciência de suas noções de mérito e culpabilidade pessoais.

O mesmo ocorre com Padre Bartolomeu de Gusmão, em Memorial do convento. Apesar de não ser uma figura mítica, ele estava sob o jugo de uma força muito maior que a sua: a Igreja Católica do século XVIII. Nos moldes de Prometeu, o padre Bartolomeu também teve seu momento de individuação da vontade, quando optou por efetivamente alçar voo com a passarola e confirmar suas hipóteses, ainda que diante de uma inevitável punição vinda da Santa Inquisição.

Como uma extensão do poder da Igreja Católica, podemos considerar o fato de que a personagem, acima de tudo, era padre e, em consequência disso, subordinado à vontade divina e aos ditames dogmático-normativos da instituição. Entretanto, conforme atesta Vernant (2011, p. 29): “A dependência em relação ao divino não submete o homem de maneira mecânica, como um efeito à sua causa." Padre Bartolomeu, ao contrário do que se poderia esperar, é assertivo quando decide avançar em seu projeto, cumprindo um compromisso científico e artístico de fazer sua obra voar, mesmo diante do fim trágico que o contexto histórico de sua época lhe reservava.

Sobre o contexto histórico, trazemos a afirmação de Rosemary Conceição dos Santos, em Saramago: metáfora e alegoria no convento (2004, p 63):

\footnotetext{
Neste período de tempo predominava pela Europa a escolástica, filosofia cristã que aliava a razão à fé, preconizava a humildade para os pobres e asseverava os castigos que adviriam sobre aqueles que se opusessem ao Cristianismo.
}

Nesse cenário, Padre Bartolomeu abandona o dogmatismo dos princípios religiosos cristãos e privilegia os mistérios ocultos, desconsiderando "a leitura consabida dos doutores da 
Igreja, dos canonistas, das formas variantes escolásticas sobre essência e pessoa" (SARAMAGO, 2017, p. 170).

\subsection{A passarola como composição trágica da narrativa}

Para tentarmos uma aproximação entre o romance histórico Memorial do convento e a tragédia grega, utilizamos a figura da passarola que, dentre outras, consegue reunir componentes trágicos a serem utilizados como referência às questões teóricas do historiador Albin Lesky (2003).

A construção da passarola dirige nosso olhar para o terceiro protagonista do romance, o padre Bartolomeu de Gusmão, responsável pelo projeto do que seria um objeto voador semelhante ao avião dos tempos modernos. Com a certeza do sucesso e autorizado pelo poder imperial, o padre brasileiro leva adiante sua ideia, seus desenhos, enfim, seu sonho.

Porém, para fazer sua obra voar, ele precisa unir forças com os conhecimentos mecânicos de Baltasar e o dom sobrenatural de Blimunda, de recolher vontades de dentro das pessoas.

A parte mecânica, executada por Baltasar, serve para a construção efetiva da passarola, com suas engrenagens, apertos e pregos; a parte do voo, que cabe a Blimunda, restringe-se à recolha das vontades, colocando-as, sob a forma de éter, em pedras de âmbar. Com Padre Bartolomeu de Gusmão, está formada, então, a tríade que lhes permitirá criar condições de levar a passarola aos céus. Dessa forma, "a ciência, o artesanato, a magia e a arte contribuem juntos para a obra, cada um na sua medida e no seu tom, mas todos em consonância, unidos pelo mesmo objetivo, pelo mesmo sonho" (CERDEIRA, 2018, p. 59-60).

Apesar de terem a licença régia de $\mathrm{D}$. João $\mathrm{V}$, os três protagonistas sabem que o projeto é perigoso e, receosos de que a Inquisição os descubra, optam por desenvolvê-lo secretamente. A consciência da ousadia se resume a duas condições que os protagonistas assumem ao levar adiante o projeto. A primeira é a construção da passarola, que envolve elementos heterodoxos — éter, âmbar, vontades — e demanda um espaço razoavelmente grande, o que pode significar um risco frente à Inquisição.

[...] talvez que o Santo Ofício considere que há arte demoníaca nesse voo, e quando quiserem saber que partes fazem navegar a máquina pelos ares, não poderei responder-lhes que estão vontades humanas dentro das esferas, para o Santo Ofício não há vontades, há só almas, dirão que as mantemos presas, as almas cristãs, e as impedimos de subir ao paraíso, bem sabem que, querendo o Santo Ofício, são más todas as razões boas, e boas todas as razões más. (SARAMAGO, 2017, p. 211). 
A segunda condição diz respeito à própria passarola que, uma vez concluída, tornar-seia a "suprema invenção”, pois “jamais haverá asas que igualem estas” (SARAMAGO, 2017, p. 210). Alcançado o objetivo final, não restaria alternativa ao padre Bartolomeu senão revelar seu sucesso ao rei, patrocinador do projeto. Contudo, mesmo com o apoio de D. João V, o padre reconhece que não escaparia da punição, pois "El-rei, sendo caso duvidoso, só fará o que o Santo Ofício lhe disser que faça" (SARAMAGO, 2017, p. 211).

Haveria outra alternativa para as personagens, que seria o uso da própria passarola para uma fuga pelo ar, o que eles efetivamente optam por fazer; todavia, acabam sendo descobertos pelo Santo Ofício e, consequentemente, levados à punição.

A trama narrativa, tal como retomada até aqui, já permite uma aproximação com as características da tragédia grega. Na perspectiva deste enfoque, partindo da passarola, é possível trazer para nossa reflexão os pressupostos apresentados por Albin Lesky (2003).

Em seus estudos no campo do trágico, o historiador austríaco confirma a imprescindibilidade da teoria de Aristóteles para qualquer estudo sobre o tema. Lesky (2003) afirma que os gregos criaram a grande arte trágica, mas não desenvolveram uma teoria do trágico que se ampliasse além da plasmação do trágico no drama e chegasse a envolver a concepção do mundo como um todo.

Para Albin Lesky (2003), o primeiro passo em direção à tragédia é o encadeamento dos acontecimentos, das personagens e das suas motivações - elemento básico do estilo dramático.

\footnotetext{
No centro dessa criação literária ergue-se sempre o herói radioso e vencedor, aureolado pela glória de suas armas e feitos, mas ele se ergue diante do fundo escuro da morte certa que, também a ele, arrancará das suas alegrias para levá-lo ao nada, ou a um lúgubre mundo de sonhos, não melhor que o nada. (LESKY, 2003, p. 24).
}

Lesky (2003) entende que a epopeia grega traz os germes trágicos, os quais a tragédia grega utilizaria em seu teatro, especialmente com Ésquilo, Sófocles e Eurípedes. A partir deste entendimento, Albin Lesky destaca cinco requisitos para o aparecimento do efeito trágico.

O primeiro deles seria a dignidade da queda. Os heróis em alto grau (reis, imperadores, generais, grandes aventureiros) caem no infortúnio, acabando em miséria. Esse requisito configura a delimitação de uma ordem social, e coube apenas à tragédia burguesa pôr fim à ideia de que os protagonistas do acontecer trágico deviam ser reis, homens de Estado ou heróis, quando o ponto de vista saiu da classe social e passou para o humano num sentido mais 
transcendente.

A dignidade da queda ressaltada por Albin Lesky (2003) encontra interessante recorte no romance saramaguiano. Por meio da ironia, o narrador já inicia seu relato mostrando um rei - que a princípio deveria ocupar destaque, e mesmo protagonismo - provavelmente ludibriado pela Igreja e pela rainha, ao não desconfiar que a esposa já poderia estar grávida no momento da visita franciscana. A trama que envolve a cena conota um suposto conluio entre elas para convencer o rei a patrocinar a construção do Convento de Mafra em troca da benção divina. Sobre a questão, Saramago destaca a cumplicidade que a rainha D. Maria Ana "deu ao artifício franciscano" (SARAMAGO, 2017, p. 32) nas tratativas.

Utilizando-se do mesmo recurso, o narrador nos mostra também o cotidiano fastidioso que o casal real leva, quando vemos a rainha sem muito interesse sexual pelo rei, "por falta de estímulo e tempo" (SARAMAGO, 2017, p. 10).

Dessa forma, verificamos que o rei e a rainha, que deveriam ocupar lugar de respeito, caso a narrativa seguisse os moldes clássicos, são trazidos para perto do leitor, configurando uma proximidade humanística que é própria do Romantismo, mas que encontra nos romances históricos um atrelamento ficcional aos relatos oficiais do período.

O segundo requisito seria a considerável altura da queda. Segundo Lesky (2003, p. 33), o que "temos de sentir como trágico deve significar a queda de um mundo ilusório de segurança e felicidade para o abismo da desgraça ineludível." Assim como podemos verificar nos romances históricos tradicionais e em Memorial do convento, essa queda "pôs fim à ideia de que os protagonistas do acontecer trágico deviam ser reis, homens de Estado ou heróis” (LESKY, 2003, p. 33).

Concatenado ao disposto no primeiro requisito, o fim de um mundo seguro em que o rei é escolhido e enviado por Deus abre espaço para que um soldado maneta (Baltasar) e uma feiticeira (Blimunda) recebam o protagonismo na narrativa, enquanto o rei é tratado como ridículo, conforme trecho a seguir, quando um diálogo entre o rei e seu tesoureiro aponta para os suntuosos gastos da coroa portuguesa:

Mas graças sejam dadas a Deus, o dinheiro não tem faltado, Pois não, e a minha experiência contabilística lembra-me todos os dias que o pior pobre é aquele a quem o dinheiro não falta, isso se passa em Portugal, que é um saco sem fundo, entra-lhe o dinheiro pela boca e sai-lhe pelo cu, com perdão de vossa majestade, $\mathrm{Ah}$, ah, ah, riu o rei, essa tem muita graça, sim senhor, queres tu dizer na tua que a merda é dinheiro, Não, majestade, é o dinheiro que é merda, e eu estou em muito boa posição para o saber, de cócoras que é como sempre deve estar quem faz as contas do dinheiro dos outros. (SARAMAGO, 2017, p. 318-319). 
Para concluir, sobre a ausência de tratamento respeitoso à figura real e o rebaixamento que o rei encontra no romance, o narrador, utilizando-se de ironia, traz um tom "absolutamente prosaico e incompatível com a magnificência real” (CERDEIRA, 2018, p. 33), e complementa:

Este diálogo é falso, apócrifo, calunioso, e também profundamente imoral, não respeita o trono nem o altar, põe um rei e um tesoureiro a falar como arrieiros em taberna, só faltava que os rodeassem inflamâncias de maritornes, seria um desbocamento completo, porém, isto que se leu é somente a tradução moderna do português de sempre [...] (SARAMAGO, 2017, p. 319).

O terceiro requisito, que pode atribuir o grau trágico tanto à arte quanto à vida, seria a possibilidade de relação com nosso próprio mundo. A narrativa deve ser tocante o suficiente para interessar-nos, afetar-nos, comover-nos. Somente quando "nos sentimos atingidos nas profundas camadas de nosso ser, é que experimentamos o trágico. Sem dúvida, para a obra trágica importa pouco que o ambiente em que se desenrola a ação seja especialmente digno de fé" (LESKY, 2003, p, 33).

A possibilidade de relação com nosso próprio mundo confere ao romance histórico o efeito de subtrair-se, "em larga medida, do tempo" (LESKY, 2003, p. 33), expandindo a possibilidade de a narrativa alcançar o presente, por meio de conflitos e vulnerabilidades da existência humana que todos experimentamos, mesmo que mais de dois mil anos nos afastem de $O$ Édipo Rei.

O mesmo argumento está presente nas narrativas de romances históricos, incluindo Memorial do convento. Trata-se de um relato ficcional em que um fato histórico é trazido a nós: a construção do Palácio Nacional de Mafra, no início do século XVIII, levada adiante por um monarca absolutista chamado D. João $\mathrm{V}$, além da própria passarola - idealizada pelo padre Bartolomeu de Gusmão - , cuja efetiva existência está apontada em registros históricos, ainda que na condição de projeto a ser finalizado.

O quarto requisito seria: uma vez identificado o conflito insolúvel na narrativa trágica, o sujeito do ato deve sofrer tudo conscientemente. "A tragédia nasceu do espírito grego e, por isso, a prestação de contas [...] é um de seus elementos constitutivos.” (LESKY, 2003, p. 34). A Antígona de Sófocles, caminhando para a morte, é um exemplo claro.

Entre outros trechos que podem ser destacados acerca do sofrimento consciente indicado por Lesky (2003), voltemos para o mesmo recorte proposto no subitem anterior, no qual é possível acompanhar a peregrinação dos cerca de seiscentos trabalhadores que carregavam enorme pedra para a região da construção. Embora discordem das ordens vindas 
de Sua Majestade e estejam conscientes dos sacrifícios que envolvem tal empreendimento, aceitam a inevitabilidade trágica.

[...] e tudo por causa de uma pedra que não precisaria ser tão grande, com três ou dez mais pequenas se faria do mesmo modo a varanda, apenas não teríamos orgulho de poder dizer a sua majestade. (SARAMAGO, 2017, p. 287).

O quinto e último requisito - que guarda controvérsias, mas que, em muitas teorias modernas, foi convertido em ponto central e requisito primordial para a realização da autêntica tragédia — é a absoluta falta de solução para o conflito trágico.

A peça séria de lenda heróica, tratada pela tragédia, contém em geral acontecimento repleto de sofrimentos. Como esse acontecimento doloroso é que assegura o efeito que Aristóteles reconheceu como específico, ou seja, o desencadeamento liberador de determinados afetos, foi ele necessariamente considerado, em grau cada vez maior, como o que caracterizava propriamente a tragédia. (LESKY, 2003, p. 37).

Obrigados a empregar suas forças de trabalho na construção do Convento de Mafra, as dezenas de milhares de operários e soldados, no romance representados por Blimunda e Baltasar, não têm escolha senão aceitar a imposição da Coroa Portuguesa, mesmo que nenhum benefício tal empreitada traga a eles. O sofrimento aqui mostra-se inevitável, pois foram inúmeros os relatos trágicos registrados na memória desse tempo.

\section{Referências:}

BASTOS, Alcmeno. Introdução ao romance histórico. Rio de Janeiro: EdUERJ, 2007.

BETHENCOURT, Francisco. História das inquisições: Portugal, Espanba e Itália. São Paulo: Companhia das Letras, 2000.

CERDEIRA, Teresa Cristina. José Saramago entre a história e a ficção. Belo Horizonte: Moinhos, 2018.

CERDEIRA, Teresa Cristina. O avesso do bordado. Lisboa: Editorial Caminho, 2000.

CINTRA, Rodrigo Suzuki. Shakespeare e Maquiavel. São Paulo: Alameda, 2015.

EAGLETON, Terry. Doce violência: a ideia do trágico. São Paulo: Unesp, 2013.

EURÍPEDES et al. O melhor do teatro grego. Tradução de Mário da Gama Kury. Rio de Janeiro: Zahar, 2013. 
FILHO, Linhares. "Uma leitura de Memorial do convento”. In: BERRINI, Beatriz (Org.) José Saramago: uma homenagem. São Paulo: EDUC, 1999.

JAEGER, Werner. Paidéia. São Paulo: Martins Fontes, 1989.

KURY, Mário da Gama. Dicionário de mitologia grega e romana. Rio de Janeiro: Jorge Zahar, 2008. LESKY, Albin. A tragédia grega. São Paulo: Editora Perspectiva, 2003.

MARINHO, Maria de Fátima. O romance histórico em Portugal. Porto: Campo das Letras, 1999.

NUNES, Benedito. “A visão romântica” In: GUINSBURG, J. (Org.) O romantismo. São Paulo: Perspectiva, 2013.

SANTOS, Rosemary Conceição dos. Saramago: metáfora e alegoria no convento. São Paulo: Scortecci, 2004.

SARAMAGO, José. Memorial do convento. São Paulo: Companhia das Letras, 2013.

VERNANT, Jean-Pierre. Mito e religião na Grécia antiga. São Paulo: WMF Martins Fontes, 2006.

VERNANT, Jean-Pierre; VIDAL-NAQUET, Pierre. Mito e tragédia na Grécia antiga. São Paulo: Perspectiva, 2011. 